\title{
Evaluating the Effectiveness and Efficiency of Tax Administration System in Ghana, Case Study of Sunyani Municipal Assembly
}

\author{
SAMPSON Atuahene ${ }^{1}$; KONG Yusheng ${ }^{2}$; GEOFFERY Bentum-Micah ${ }^{3}$ \\ ${ }^{1}$ School of Finance and Economics, Jiangsu University, Zhenjiang, China \\ * corresponding author \\ ${ }^{2}$ Professor, Research Institute of Industrial Economics, Jiangsu \\ University, Zhenjiang, China \\ ${ }^{3}$ PHD Candidate, School of Management, \\ Jiangsu University, Zhenjiang,
}

\begin{abstract}
In as much as most countries benefit from external sources of funds and grants, her major reliable source of fund is the one generated internally. In a developing country, taxation is one of the major forces behind which the country can develop. Whiles Ghana Revenue Authority is one of the agencies which can mobilize such funds for the benefit of the nations; it is not easy to find tax payers for assessment and eventually to pay their taxes. This study evaluated the efficiency and effectiveness of the tax administration system of the Ghana Revenue Authority (GRA).

The field of the tax administration is of major importance to any tax system. The research brought to light that there is lack of the characteristics of a good tax system that is equity, certainty, convenience and economy. The legal structure is complex and includes axes - related laws, decrees, and rulings.
\end{abstract}

Keywords: Tax Administration, Taxpayer; Taxation, Municipal, Revenue

\section{Introduction}

From the days of Pharaohs in Egypt to modern day government, tax and taxation has always been part of society. There have being various reasons as to why taxes are being imposed. And there are various tax administration systems that have been adopted throughout history. In order to fund various government projects, tax is introduced as a compulsory charge, levied on individual and entities in a given society. The word tax is from a Latin word "taxo" which can be defined as a mandatory financial charge or some other type of levy imposed upon an individual or other legal entity (Taxpayer) by a governmental organization in order to fund various public expenditures (Wikipedia.com). There is a serve punishment for refusal to pay taxes and underpayment of taxes across all nations. We can ground tax in to two different forms; direct and indirect taxes. Shirley and Karen 2012 defined tax is a 'forced payment made to a governmental unit that is unrelated to the value of goods or services provided'. Before 2009, Ghana had various independent institutions and agencies in charge of tax collections and administration. However, in December 2009, the three revenue agencies that is Customs Excise and Preventive Service, Internal Revenue Service, Value Added Tax Service and Revenue Agencies Governing Board Secretariat were merged in accordance with the Ghana Revenue Authority Act, 2009 (Act 791). GRA thus replaces the revenue agencies in the administration of taxes and customs duties in the country.

Rai 2004 stated that collections of taxes is mandatory responsibility for all civilized countries. The reasons why taxes should be collected includes; to meet their day-to-day expenses related to maintenance of a free and fair society, to finance developmental activities, to control the economy through fiscal measures, and to a certain extent, to change the economic behavior of people. ax administrations modern in era seek to optimize tax collections while minimizing administration costs and taxpayer compliance costs (Okello 2014). There is still room for improvement in the design and delivery of client-focused taxpayer service programs, and better engage with the private sector and other stakeholders. The United states Tax 
administration, defined tax administration as the administration, management, conduct, direction, and supervision of the execution and application of the internal revenue laws or related statutes (or equivalent laws and statutes of a State) and tax conventions to which the United States is a party; and the development and formulation of Federal tax policy relating to existing or proposed internal revenue laws, related statutes, and tax conventions.Tax administration also includes assessment, collection, enforcement, litigation, publication, and statistical gathering functions under such laws, statutes, or conventions. (GAO report 1997)

Research has shown that, Tax leakages that occurr in developing countries happens due to poor or underresourced or under-trained administrators, poor tax collection systems, failure of legal enforcement mechanism for tax collection and small penalties for non-payment. These factors make openings for local and external entities to manipulate the system since tax official mostly lack the required technical skills to uncover complex international fiscal structures that are used to escape taxation, and because penalties are insufficient to stop tax evasion (Boakye, 2011).

In 1970 the government of Ghana tried to regionalize tax enforcement to the local level. The aim was to achieve district focused public administration. The collection of taxes especially income taxes was hence delegated to the Metro, Municipal and District office of the Ghana Revenue Authority. The main objective of the Ghana revenue authority is ensuring compliance laws.

In 2001, a new tax law, The Internal Revenue Act 2000 (Act 592), was passed to administer Direct Taxes. The Internal Revenue Regulations, 2001 (L. I. 1675) was also introduced. There have been a number of amendments to the law and regulations. Bold changes in Ghana's tax administration played a key role in improving the country's revenue mobilization and overall fiscal health (Terkper1993). Sunyani is the capital of Brong Ahafo region. The Sunyani Municipal assembly is located in the centre of Sunyani Township. It shares boundaries with the Wenchi Municipal to the north, Berekum Municipal and Dormaa East Districts to the west, Asutifi District to the south and Tano South District to the east.

As mentioned earlier, Ghana as a nation collects taxes through various means and channels, from the national, regional, metropolitan, municipal, district to various towns and villages, there believe to be systems and officials put in place and in charge to administer tax collection of which Sunyani municipal assembly is no exception. That is why this study seeks to examine how effective and efficient tax administration system is in the Sunyani Municipal. However the specific objectives includes finding out whether there are personnel responsible for the administration of the tax system in the Sunyani Municipal Assembly, confirming whether the tax officials have adequate training on the job, assessing how the tax collectors account to the authority, determining whether the tax authority gives adequate education to taxpayers, and identifying other factors if any that hinder the performance of an effective tax administration system in the Municipality.

\section{Literature Review}

\subsection{Evolution Taxation in Ghana}

Income tax was introduced in Ghana when the poll tax ordinance was passed within the period 1852 and 1892. It was however abolished when the poll tax became outmoded. Sir Radford Stanley, the then governor of Gold Coast proposed the imposition of income tax at the rate of six pence in pound sterling of all incomes. The new tax did not last long as a result of serious world-wide economic depression, which made life unbearable. The tax policy of the government went through series of transformation until 2009 when the GRA was established under the Ghana Revenue Authority Act, 2009 (Act 791). The Act was given presidential assent on December 31, 2009. The Act was aimed at improving tax payer service and processes in Ghana tax system and custom offices as well as ensuring a high level of compliance by the taxpayer.

\subsection{Education and Campaign}

As with all taxes, education and attention should be given to taxpayers on the rational, procedures, obligations and responsibilities related to the business license and property tax. Having the ability to link revenue collection to improved service delivery, and a better-educated taxpayer population will enhance compliance. Mobilizing the community through enhanced participatory budgeting and civic participation and also facilitates revenue collection.

Among the education given to the tax payers include the following;

\subsubsection{The Right to Be Informed}

Taxpayers have the right to know what they need to do to comply with the tax laws. They are entitled to clear explanations of the laws and IRS procedures 
in all tax forms, instructions, publications, notices, and correspondence. They have the right to be informed of IRS decisions about their tax accounts and to receive clear explanations of the outcomes.

\subsubsection{The Right to Quality Service}

Taxpayers have the right to receive prompt, courteous, and professional assistance in their dealings with the IRS, to be spoken to in a way they can easily understand, to receive clear and easily understandable communications from the IRS, and to speak to a supervisor about inadequate service.

\subsubsection{The Right to Pay No More than the Correct Amount of Tax}

Taxpayers have the right to pay only the amount of tax legally due, including interest and penalties, and to have the IRS apply all tax payments properly.

\subsubsection{The Right to Challenge the IRS's Position and} Be Heard

Taxpayers have the right to raise objections and provide additional documentation in response to formal IRS actions or proposed actions, to expect that the IRS will consider their timely objections and documentation promptly and fairly, and to receive a response if the IRS does not agree with their position.

\subsubsection{The Right to Appeal an IRS Decision in an Independent Forum}

Taxpayers are entitled to a fair and impartial administrative appeal of most IRS decisions, including many penalties, and have the right to receive a written response regarding the Office of Appeals' decision. Taxpayers generally have the right to take their cases to court.

\subsubsection{The Right to Finality}

Taxpayers have the right to know the maximum amount of time they have to challenge the IRS's position as well as the maximum amount of time the IRS has to audit a particular tax year or collect a tax debt. Taxpayers have the right to know when the IRS has finished an audit.

\subsubsection{The Right to Privacy}

Taxpayers have the right to expect that any IRS inquiry, examination, or enforcement action will comply with the law and are no more intrusive than necessary, and will respect all due process rights, including search and seizure protections and will provide, where applicable, a collection due process hearing.

\subsubsection{Right to Confidentiality}

Taxpayers have the right to expect that any information they provide to the IRS will not be disclosed unless authorized by the taxpayer or by law. Taxpayers have the right to expect appropriate action will be taken against employees, return preparers, and others who wrongfully use or disclose taxpayer return information.

\subsubsection{The Right to Retain Representation}

Taxpayers have the right to retain an authorized representative of their choice to represent them in their dealings with the IRS. Taxpayers have the right to seek assistance from a Low-Income Taxpayer Clinic if they cannot afford representation.

\subsubsection{The Right to a Fair and Just Tax System}

Taxpayers have the right to expect the tax system to consider facts and circumstances that might affect their underlying liabilities, ability to pay, or ability to provide information timely. Taxpayers have the right to receive assistance from the Taxpayer Advocate Service if they are experiencing financial difficulty or if the IRS has not resolved their tax issues properly and timely through its normal channels.

\subsection{Education and training}

Education and training of the tax officials is an indispensable element in tax administration in the country. Training involves improving the skills, knowledge and attitudes of employees so as to become more efficient and productive. However, because the tax officials are already enlightened and also have the qualification required, their training process becomes easy and flexible; their understanding of the system and the taxpayer is great satisfaction. Among the types of training given to the tax officials are:

\subsubsection{Induction Training}

It involves introducing a new employee to its work environment. Usually, it includes, introduction to colleagues, explaining the firm's activities, procedures followed in the organisation, explaining the organisational structure, Place of working etc.

\subsubsection{On the Job training}

A worker gets training by watching a more experienced worker doing the job. It is common for unskilled and semi-skilled jobs. Thus, the worker gets trained while he is performing his regular duties.

\subsubsection{Off the job training}

This is when a worker goes away from the place of work to attend a special course. The training can be in the form of a seminar, workshop or a college course. Off the job training is usually conducted for managerial level employees. The objectives of training include, improve the efficiency of workforce, make workers multi-skilled and flexible, introducing a new process or new machinery, reduce wastage of material and time and adapt to change 


\subsubsection{Accountability}

As with all systems, accountability is an indispensable element as far as monetary issues are concern and GRA officials are no exception. In response to the proper accountability of tax officials, the researchers found that the revenue or monies collected by the tax officials are paid to the office cashier who in turns makes the necessary entries in the cash book after which payments are affected or made into the consolidated fund. Payments sometimes are made twice a day; revenues received by the tax officials are paid to the office cashier to be paid into the consolidated fund before mid-day payments are again made. This is done with the view to meeting the target for the month and hence the years target.

However, where money is brought in late and could not be paid in that same day, payment could be made on the next day with the next day's date even where the next date is a new month. The mode of payment however, is mostly cash-basis (cash-basis taxpayers) but with a few cases of cheque by the tax payer.

\section{Methodology}

The study employed descriptive method of research. The set of hypothesis indicates that the relationship between the variables should be tested using different statistical techniques. The sample size chosen for the study was one hundred (105) respondents which constitute eighty (83) taxpayers and twenty (22) tax officials. However out of the 105 questionnaires administered 5 of the 3 from the taxpayers and 2 from the tax officials had error so they could not be analyzed. 100 questionnaires were however perfect for the analysis. The collection agencies known as the Ghana Revenue Authority (GRA) were considered. This was because the researchers wanted the sample to suit the purpose of the study. Hence in the Municipality, GRA was selected. Our belief is that, the above sample used in this category was enough to provide the data needed for the study. The types of data used for the purpose of this research are the primary and secondary data.

Simple statistical techniques were used in analyzing and summarizing the gathered data. Descriptive analysis was used with the aim of making the data more comprehensive. The data was also analyzed quantitatively in consonants with the overall objectives of the study.

The analysis of data entails a lot but the researchers used frequency tables with score applied to the variables involved. This was done by using quantitative data to come out with qualitative meanings and explanations as well as possible implications.

Percentage analysis was also used to draw the relationship of the views of the respondents and the total respondents; these are displayed in table form for easy assimilation.

It is against this background that appropriate recommendations consequent to findings of the research could be made.

\section{Results Of Findings}

In order to evaluate the efficiency and effectiveness of the tax administration system in Ghana, questionnaires were designed and distributed to tax officials and tax payers to obtained views on the tax administration system in Ghana. This chapter presents results and discussion on the findings made. To assess the effectiveness of income tax administration in GRA, within Sunyani Municipality and to arrive at meaningful conclusion, the researcher aim at analyzing the data collected in relation to the purpose of the study. The firms involved in this regard are the Ghana Revenue Authority and the self-employed enterprises within Sunyani Municipality.

\subsection{Tax Officials}

Questionnaires that were designed for the tax officials were given to the officials of the GRA services of the Sunyani Regional office

\subsubsection{Gender}

\section{Table 4.1: Gender of Tax Officials}

\begin{tabular}{|l|c|r|}
\hline & Frequency & Percentage \\
\hline Males & 13 & 65 \\
\hline Females & 7 & 35 \\
\hline Total & 20 & 100 \\
\hline
\end{tabular}

\section{Source: Field Survey, September, 2018}

Analyses from table 1 shows that 13 out of the 20 respondents were males, which represent $65 \%$ of the respondents Also, 7 out of the 20 respondents, were females, which represents $35 \%$ of the total of respondents. This indicates that females' staffs are relatively high.

\subsubsection{Educational Status}


Table 4.2: Education Status of Tax Officials.

\begin{tabular}{|l|l|l|}
\hline Qualification & Frequency & $\begin{array}{l}\text { Percentage } \\
(\%)\end{array}$ \\
\hline University & 9 & 45 \\
\hline Polytechnic & 5 & 25 \\
\hline Secondary & 2 & 10 \\
\hline Technical & 4 & 20 \\
\hline Total & 20 & 100 \\
\hline
\end{tabular}

\section{Source: Field Survey, September, 2018}

The question was meant to investigate the highest educational level of the tax officials. From table two, out of the 20 respondents, 9 were university graduates which represent $45 \%$ of the total; Also 5 out of the 20 respondents were polytechnic graduates which represent $25 \%$, another 2 out of the 20 respondents were Secondary graduate which representing $10 \%$ of the respondents. Further 4 out of the 20 were technical graduates representing $20 \%$ of the respondents. This shows that most of the respondents or officials are of higher educational background.

a) On the job Training

Figure 1 Information on job Training

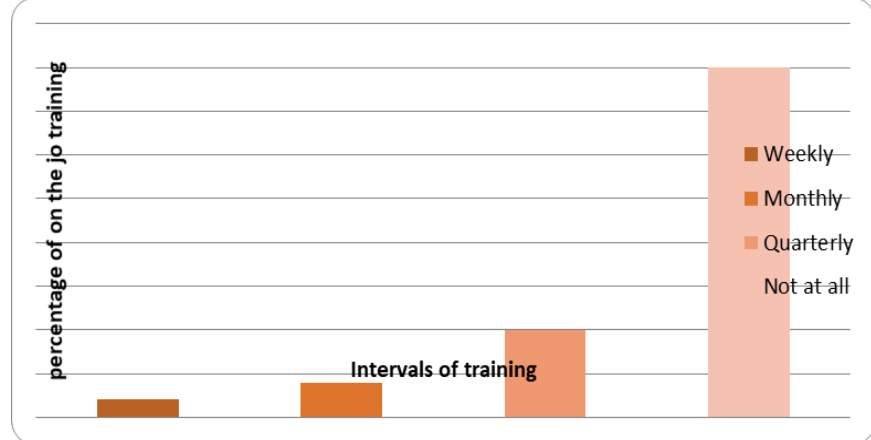

Source: Field Survey, September, 2018

Figure 1 shows how often staff of GRA undergo training. Out of the 20 respondents, ten percent $(10 \%)$ each said they undergo training on weekly and quarterly basis respectively and twenty percent (20\%) said they undergo training on monthly basis. Sixty percent $(60 \%)$ said they do not undergo training at all which constitutes majority of the staff perhaps staffs that are on the forefront of tax collection.

\section{b) Position/Ranking}

The ranks of the tax officials of the GRA are as follows: The Board Commissioner, Deputy
Commissioner, Assistant Commissioner, Chief inspector of Taxes, Tax Assistant and that of the CEPS is the same as the Domestic Tax Revenue.

However, the respondent's ranks at Domestic Tax Revenue are range between the principal Inspector of taxes, Assistant Inspector of taxes and junior tax Assistants. Those of the respondents from the CEPS are Senior Officers Exports, Assistant Collectors and Collectors.

\subsubsection{Job Experience}

Table 4.3: Job Experience of Tax Officials.

\begin{tabular}{|l|l|l|}
\hline Years & Frequency & Percentage \\
\hline BELOW 10 YEARS & 14 & 70 \\
\hline ABOVE 10 YEARS & 6 & 30 \\
\hline TOTAL & 20 & 100 \\
\hline
\end{tabular}

\section{Source: Field Survey, September, 2018}

This was asked to know how long tax officials have worked in the service. From table 3, it shows that 14 of the respondents representing $70 \%$ have worked less than 10years while 6 respondents representing $30 \%$ of the respondents have stayed in the service for more than 10 years. This shows that, tax officials with much experience are relatively low.

\subsection{Other Sources of Income That Should Attract Taxes}

Table 4: Income That Should Attract Taxes

\begin{tabular}{|l|l|l|}
\hline INCOME & $\begin{array}{l}\text { FREQU } \\
\text { ENCY }\end{array}$ & $\begin{array}{l}\text { PERCENT } \\
(\%)\end{array}$ \\
\hline PRESIDENT ALLOWANCES & 8 & 40 \\
\hline ONE MAN CHURCHES & 6 & 30 \\
\hline FUND RAISING BY & 6 & 30 \\
\hline TOTAL & 20 & 100 \\
\hline
\end{tabular}

\section{Source: Field survey, September, 2018}

Most of the respondents were of the view that allowances of the president, Income from Fundraising by political parties representing $40 \%$ as shown in table 4 while income from one-man churches and funds raise by political 
parties represents 30\% each. The reasons cited were that the president is an employee as those in private and public sectors and one-man churches generate a lot of money which should attract taxes to increase the tax revenue in the country.

Those who were of the view of expanding the sources mentioned sources such as income of commercial sex workers, Tips given to Bar Restaurant attendants, churches, Gambling and imported vehicles. Their reasons were that, most of the above-mentioned sources generate as much income as those which are already being taxed under the GRA law. This is an indication that there are many individuals and institutions who are earning income but do not pay tax.

\subsection{Information about Tax Payers}

Table 5: Sources of Information about Taxpayers.

\begin{tabular}{|l|l|l|}
\hline RESPONSE & FREQUENCY & $\begin{array}{l}\text { PERCEN } \\
\text { TAGE }\end{array}$ \\
\hline YES & 18 & 90 \\
\hline NO & 2 & 10 \\
\hline TOTAL & 10 & 100 \\
\hline
\end{tabular}

\section{Source: Field Survey, September, 2018}

Responses from the IRS and the CEPS on how information is collected on tax payers were almost the same. Respondents state that, they get information from taxpayers Files, through field exercises, Town and Market Survey, Income tax form 21,22a and 22 completed by taxpayers. Other sources were through interview with the taxpayers through public informants that are media, which is both electronic and print media.

Based on the responses, market survey and Taxpayers file are the major source of information about taxpayers and this file is and survey like all other surveys do not provide $100 \%$ coverage. This implies that most income earners especially the self-employed are not covered by the tax net.

\subsection{Tax Evaders}

Table 6: Information about Tax Evaders.

\begin{tabular}{|l|l|l|}
\hline SOURCE & $\begin{array}{l}\text { FREQUN } \\
\text { CY }\end{array}$ & PERCENT \% \\
\hline INFORMANTS & 4 & 20 \\
\hline $\begin{array}{l}\text { EXTERNAL } \\
\text { INSPECTION }\end{array}$ & 12 & 60 \\
\hline $\begin{array}{l}\text { REGISTRAR GENERAL } \\
\text { DEPT }\end{array}$ & 4 & 20 \\
\hline TOTAL & 20 & 100 \\
\hline
\end{tabular}

Source: Field Survey, September, 2018.

On the issue of how tax evaders are identified, the respondents stated sources such as informant, external inspection and through registrar General Department of those registered business. Based on the above sources; understatement of returns and qualified taxpayers who have not registered with the offices could be detected. From table 6, it shows that $60 \%$ of the respondents were of the view that external inspection is the best way to identify tax evaders while informants and registrar General dept accounted for $20 \%$ each.

Table 7: Responses on Revenue Exceeding the Estimated

\begin{tabular}{|l|l|l|}
\hline SOURCE & $\begin{array}{l}\text { FREQUENC } \\
Y\end{array}$ & $\begin{array}{l}\text { PERCENT } \\
(\%)\end{array}$ \\
\hline TAXPAYERS FILE & 12 & 60 \\
\hline $\begin{array}{l}\text { TOWN AND MARKET } \\
\text { SURVEY }\end{array}$ & 8 & 40 \\
\hline INCOME TAX FORM & - & - \\
\hline TOTAL & 20 & 100 \\
\hline
\end{tabular}

\section{Source: Field Survey, September, 2018.}

All the responses made here were positive. Reasons that were given are dedication of staff to their work, collection of tax arrears pending, and intensive publicity Others were the acceptance of the system by the taxpayers, identification of new taxable traders that is widening the tax net and education of taxpayers. This indicates that, the estimated target can sometimes be exceeded and this is the time the government get more revenue to finance its projects.

\section{Table 8: Responses on Revenue Fallen Short of the Estimated.}

\begin{tabular}{|l|l|l|}
\hline REPONSES & FREQUENCY & $\begin{array}{l}\text { PERCENTA } \\
\text { GE \% }\end{array}$ \\
\hline YES & 20 & 100 \\
\hline NO & - & - \\
\hline TOTAL & 20 & 100 \\
\hline
\end{tabular}


Source: Field Survey September, 2018.

According to the responses that were given $90 \%$ of the total respondents admitted that there used to be short falls in estimates while $10 \%$ of them were of the contrary view. However, all the respondents from the CEPS indicate that their targeted estimates are always achieved? This shows that the target that is being set by the administrators cannot always be achieved, especially as in the case with the Domestic revenue Department. There may sometimes be a shortfall and this is attributable to the level of tax evasion, underestimate of profits by taxpayers and over estimation by tax administrators.

\subsection{Tax Payers}

Questionnaires that were designed for taxpayers were given to individuals such as selfemployed/traders, corporate bodies and employees.

\section{Age Group}

Item 1 of the questionnaire generated information on the age of the respondents.

Table 9: Age of Respondents

AGE FREQUENCY

$25-35$ 40

$36-45$

46-55 15

56 and above 5

TOTAL 80

\section{Sources: Field Survey, September, 2018}

Out of the 80 respondents from the taxpayers $50 \%$ of them were between the ages of 25 and $35,25 \%$ of them were between the ages of 36 and $45,19 \%$ were between the ages of 46 and 55, 6\% were between the ages 56 and above. This indicates that most taxpayers are in their youthful age.

\section{Table 10: Gender of Taxpayers}

\begin{tabular}{|l|l|l|}
\hline Sex & $\begin{array}{l}\text { Frequenc } \\
\mathrm{v}\end{array}$ & Percentages $(\%)$ \\
\hline Male & 55 & 69 \\
\hline Female & 25 & 31 \\
\hline Total & 80 & 100 \\
\hline
\end{tabular}

\section{Source: Field Survey, September, 2018}

Out of the 80 respondents, 55 of them were males and 25 of them were females representing $69 \%$ and
$31 \%$ respectively. This shows that most of the taxpayers are males who are mainly family breadwinners, hence are more concerned about how to gain income than paying their tax.

\subsection{Imposition of Taxes}

The response from taxpayers as to why taxes are imposed includes, generating revenue for the country to embark on developmental projects and to finance government expenditure and only one person said taxes are misused by the leaders of the country. It can be noted that all the respondents virtually talked about the same thing:

That is, taxes are imposed on citizens in order to raise revenue for development. This is indicative of the fact that most taxpayers have a fair idea on why taxes are imposed.

\section{4..7 Necessity in the Payment of Tax}

Respondents were asked to indicate whether taxes are really necessary.

TABLE 11: Rational Behind the Payment of Tax Source: Field Survey, September, 2018

From table 11, $94 \%$ of the respondents indicated that itPERCFedifyGFecessary to impose taxes, while 690 of the respondents indicated that it is not

\begin{tabular}{|l|l|l|}
\hline Respop & Frequency & Percentage $(\%)$ \\
\hline Yes 19 & 75 & 94 \\
\hline No 6 & 5 & 6 \\
\hline Total $^{6}$ & 80 & 100 \\
\hline
\end{tabular}
necessary to impose tax.

Figure 2 Education on tax and filing of tax returns

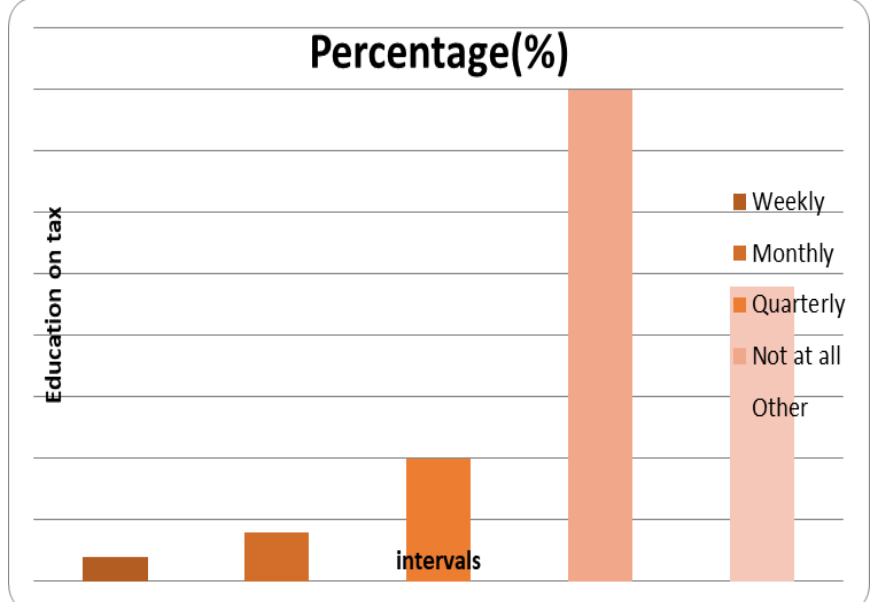

Source: Field Survey, September, 2018

Objective two: To find out whether tax collecting receive adequate training. Two percent $(2 \%)$ of the respondents said they hear or get education concerning tax and filing of tax returns while four percent $(4 \%)$ and ten percent $(10 \%)$ said they get 
education on tax and filing of tax returns on monthly and quarterly basis respectively. Forty percent (40\%) of the respondents said they do not get any education from GRA at all which constitute the majority while twenty-four percent $(24 \%)$ of the respondents who answered "other" gave reasons that they get education from GRA but not on regular basis.

Table 11: Convenience with the Amount of Tax Being Paid

\begin{tabular}{|l|l|l|}
\hline Response & Frequency & $\begin{array}{l}\text { Percentage } \\
(\%)\end{array}$ \\
\hline YES & 60 & 75 \\
\hline NO & 20 & 25 \\
\hline Total & 80 & 100 \\
\hline
\end{tabular}

\section{Source: Field Survey; April 2017}

Analysis from table four depict that 60 respondents answer Yes which represent $75 \%$ and 20 respondents answered NO which represents $25 \%$ of the total. The respondents who ticked Yes stated that, the tax system is not fair as single commodity can attract so many taxes. Most of those respondents who ticked Yes are selfemployed and corporate bodies; they stated that the tax rates are not reasonable and that they should be reduced. Those whose response was No stated that, with the presence of the tax they are still able to meet obligations with ease and that it is only a small percentage of their salary. Some of the respondents here did not respond to the second part of the question. What has been deducted from the analysis shows that those who earn less do not have enough money left for their needs.

Table 12: How Often Taxes Are Paid

\begin{tabular}{|l|l|l|}
\hline Response & $\begin{array}{l}\text { Frequ } \\
\text { encv }\end{array}$ & Percentage $(\%)$ \\
\hline Monthly & 30 & 38 \\
\hline Quarterly & 42 & 53 \\
\hline Annually & 8 & 10 \\
\hline & & \\
\hline \hline Total & 80 & 100 \\
\hline
\end{tabular}

Sources: Field Survey, September, 2018

From table 13, it indicates that $38 \%$ of the respondents pay their taxes monthly, 53\% pay their taxes quarterly and, $10 \%$ of them pay their taxes annually. This shows that most taxpayers pay their taxes quarterly.

\section{Table 15: Chargeable Incomes of Taxpayers}

\begin{tabular}{|l|l|l|}
\hline Chargeable Income & Frequency & Percentage (\%) \\
\hline $\begin{array}{l}\mathrm{GH} \varnothing 50.00-\mathrm{GH} \phi \\
10,000.00\end{array}$ & 15 & 19 \\
\hline $\begin{array}{l}\mathrm{GH} \phi 10,001.00-\mathrm{GH} \phi \\
20,000.00\end{array}$ & 20 & 25 \\
\hline $\begin{array}{l}\mathrm{GH} \varnothing 20,001.00-\mathrm{GH} \phi \\
35,000.00\end{array}$ & 10 & 12 \\
\hline $\begin{array}{l}\mathrm{GH} \varnothing 35,001.00-\mathrm{GH} \phi \\
50,000.00\end{array}$ & 3 & 4 \\
\hline $\begin{array}{l}\mathrm{GH} \varnothing 50,001.00-\mathrm{and} \\
\text { above }\end{array}$ & 32 & 40 \\
\hline Total & 80 & 100 \\
\hline
\end{tabular}

\section{Source: Field Survey, September, 2018}

Table fifteen reveals that 15 of the respondents have a chargeable income between $\mathrm{GH} \phi 500.00$ and $\mathrm{GH} \phi 10,000.00$ representing $19 \%$ of the total respondents, 20 of them have a chargeable income between $\mathrm{GH} \phi \quad 10,001.00$ and $\mathrm{GH} \phi \quad 20,000.00$ representing $25 \%$ of the respondents, 10 have chargeable income between $\varnothing 21,000$ and $\varnothing 35,000$ representing $12 \%$ of the respondents, 3 of have chargeable income between $\mathrm{GH} \phi 35,001$ and $\mathrm{GH} \phi$ 50,000 representing $4 \%$ of the respondents and 32 have chargeable income between $\mathrm{GH} \phi 50,001$ and above representing $40 \%$ of the respondents. It can be deduced that majority of the respondents fall between $\mathrm{GH} \phi 10,001.00$ to $\mathrm{GH} \phi .20,000.00$ and $\mathrm{GH} \notin 51,000.00$ and above. This implies that most of respondents were small and medium businesses who make much profit and hence much chargeable income base.

\section{Discussion Of Research Findings}

Analysis of the results the data are interpreted per the research objectives that we set at the beginning of the research. Out of the research objectives that the research questions were formed and base on that we developed our questionnaires and also find related secondary data.

\subsection{Finding out whether there are personnel responsible for the administration of the tax system in the Sunyani Municipality.}

The research revealed that there is inadequate of personnel and experience personnel responsible for the administration of taxes. The few that are there 
are not fully equipped to execute their duties. This is in line with table 3 which shows that majority of respondents have working experience between 0 and 10years representing forty $(40 \%)$ while thirty percent $(30 \%)$ of the respondents have working experience above ten (10) years.

The Ghana revenue Authority relies mainly on office audit, which entails small business and company returns. This does not involve extensive scrutiny of the taxpayer's books and records. In this process the office of auditor examines the returns of individuals and companies under his schedules.

\subsection{Finding out whether the tax officials have adequate training.}

There are problems of adequate of training. This does not give the tax officials the technical knowhow of the tax system and they cannot explain the complex legal structure of the administration which includes related laws, decrees and rulings to tax payers and this create problems on the part of tax officials and tax payers. This is clearly shown on figure 1 of which forty percent $(40 \%)$ of the respondents said they do not get on the job training to enhance their knowledge on the tax system.

\subsection{Assessing how the tax collectors account to the authority:}

As with all systems, accountability is an indispensable element as far as monetary issues are concerned and GRA officials are no exception. In response to the proper accountability of tax officials, the researcher found out that the revenue or monies collected by the tax officials are paid to the office cashier who in turns makes the necessary entries in the cash book after which payments are affected or made into the consolidated fund. Payments sometimes are made twice a day; revenues received by the tax officials are paid to the office cashier to be paid into the consolidated fund before mid-day payments are again made. This is done with the view to meeting the target for the month and hence the years target.

\subsection{Determining whether the tax authority gives adequate education to taxpayers on the importance of tax system.}

Some taxpayers stated that education on tax and filing of tax returns are lacking. This shows that there are problems the taxpayers encounter with Ghana Revenue Authority. Most taxpayers are illiterates; and therefore, do not know how to keep proper books of accounts. Others also intentionally refuses to release information on their businesses or refuse to file returns since they are not educated on the importance of tax and how revenue from tax is being utilized. This is shown in figure 2. From figure 2 , forty percent $(40 \%)$ of the respondents said they do not get education on tax and filing of tax returns. Twenty-four percent $(24 \%)$ of them said they sometimes get education but not on regular basis.

5.5 Identifying other factors if any that hinder the performance of an effective tax administration system in the Municipality.

There is lack of the characteristics of a good tax system that is equity, certainty, convenience and economy. The legal structure is complex and includes axes - related laws, decrees, and rulings. There often exists an overlapping and contradictory tax. Many of these taxes overlaps so that a single commodity of transaction may be subjected to a number of taxes, imposed at different or supplementary rates involving different tax bases with different times of payment, different returns and separate administrative and judicial procedures. Some of these taxes are obsolete, yielding only very small revenue or sometimes nothing at all, but remains on the books to complicate the tax structure. It was ascertained that there is political influence in the appointment of officials. The result of this is that appointment especially of top-level officials is based on the obnoxious principle of square peg being put in to round hole.

This simply means appointment is based on nepotism and not on merit. As to the matter of pay scales, the results of inadequate salaries are obvious, they attract mainly the incompetent; they lead to part-time employment with its problems of divided loyalty and inadequate attention to the government's work; they breed dishonesty, bribery and corruption. With hard-pressed budgets, the vicious circle of low pay-incompetent personnel- undesirability of increasing the salaries of an incompetent staff cannot be avoided.

\section{Conclusions}

The prior discussion has considered various aspect of tax administration, its problems and has indicated possible points of improving the efficiency and effectiveness with respect to existing procedures. If the tax system works as required, it will increase the revenue obtained from taxes to enable government to carry out their economic planning on a more beneficial ground. Irregular visit on the part of tax officials to audit the accounts of taxpayers to make sure the right tax is paid is making taxpayers unfaithful to the 
government because they under estimate the amount of receipts collected for a period.

There are problems of poor condition of service and lack of training. This does not give the tax officials the technical know-how of the tax system and they cannot explain the complex legal structure of the administration which includes related laws, decrees and rulings to tax payers and this create problems on the part of tax officials and tax payers.

Political influence in the appointment of officials, especially of top-level officials is based on the obnoxious principle of square peg being put in to round hole and this hinders the development of the country because the right person is not chosen for the right job.

Also lack of principles like equity, certainty, convenience and economy is causing problem on the side of both tax officials and taxpayers. Legal structure is complex and includes many taxesrelated laws, decrees and rulings and should be made flexible for the understanding of everyone because it does not offer any benefit in terms of revenue.

In as much as most countries benefit from external sources of funds and grants, her major reliable source of fund is the one generated internally. In a developing country, taxation is one of the major forces behind which the country can develop. Whiles Ghana Revenue Authority is one of the agencies which can mobilize such funds for the benefit of the nations; it is not easy to find tax payers for assessment and eventually to pay their taxes.

The inadequate of personnel and experience person responsible for administering of taxes in the various division of Ghana Revenue Authority can be addressed by employing qualifying and experience staff. This in line with (Annan, 2008), who said an efficient tax administration also depends to a very large extent on the caliber of personnel in the tax department. There should be an institution of appropriate training programs and seminars organized on regular basis to abreast staff with best practices in tax systems

Ghana Revenue Authority (GRA) should make good use of such media of public communication as newspapers, radio, television, posters and public bulletin boards to teach taxpayers, especially, the self-employed simple book-keeping and management techniques in order to help them contribute more to tax revenue.

There is lack of the characteristics of good tax system, complexity of legal structure and also political influence in the appointment of officials. For the tax system to be effective and efficient the tax system must possess all the characteristics of a good tax system that is equity, certainty, convenience and economy.

Since we are in the internet age, the development and the use of mobile app in the collection of taxes is highly recommended.

\section{References}

[1] Jenkins, G. P., \& Terkper, S. E. (1992). Administration Reform for Fiscal Systems in Transition Economies: The Case of Viet Nam (No. 442). Harvard Institute for International Development, Harvard University.

[2] Akorsu P. K, (2015). An Evaluation of the Effectiveness of the Revenue Mobilization in the Public Sector of Ghana: The Case Study of Case of Cape Coast Metropolitan Assembly. I.J.E.C.M United Kingdom

[3] Fosu, M. A. (2012). An Evaluation of Effectiveness of Revenue Mobilization Strategies of Metropolitan, Municipal and District Assemblies (MMDAs) in Ghana: A case study of Kumasi Metropolitan Assembly (KMA) (Doctoral dissertation).

[4] Ayee, J., Søreide, T., Shukla, G. P., \& Le, T. M. (2011). Political economy of the mining sector in Ghana. The World Bank.

[5] Gillis, M., Shoup, C. S., \& Sicat, G. P. (Eds.). (1990). Value added taxation in developing countries. World Bank.

[6] Armah-Attoh, D., \& Awal, M. (2013). Tax administration in Ghana: Perceived institutional challenges. Afro-barometer, Briefing Paper, 124.

[7] Abdallah, A. N. (2006). Taxation in Ghana: Principles, Practice, and Planning. Black Mask.

[8] Adams S, (1776). The Wealth of Nation. London: Penguin Books.

[9] Bekoe, W., Danquah, M., \& Senahey, S. K. (2016). Tax reforms and revenue mobilization in Ghana. Journal of Economic Studies, 43(4), 522-534.

[10] Adams, K., Debrah, Y. A., Williams, K., \& Mmieh, F. (2014). Causes of financial FDI inflows into sub-Saharan Africa (SSA): Evidence from Ghana. Thunderbird International Business Review, 56(5), 439459.

[11] Agyeman-Dua, E. (2005) Income Tax, Gift Tax and Capital Gains Tax with Supplementary Question. First Edition Accra: EDA Publications. 
[12] Terkper, Seth. (1998) Ghana: Tax Administration Reforms (1985-1993).

Cambridge, MA: International Tax Program, Harvard University.

[13] Terkper, S., (2007) African Tax Reform, African Development Bank Workshop. The State of the Ghanaian Economy (2007) U G, Legon ISSER Publications.

[14] Adams S, (1776). The Wealth of Nation. London: Penguin Books.

[15] Adams Smith (2009). Proposed Canons of taxation; Equity, certainty, convenience and efficiency. London: Oxford University Press

[16] Anuradha J and Ayee J, (2002), Taxing for the State? Politics, Revenue and the informal Sector in Ghana I.F.S Bulletin Vol. No. 3, p 90 Business \& Financial Times. (2011), Tax reliefs. February 23 .

[17] Chow, C.Y. (2004). Gearing up for the selfassessment tax regime for individuals. Tax National, 2nd quarter, 20-23. (Gaurav, 2010). Role of Taxation in developing Countries like India.

[18] Eriksen, K., and Fallan, L. (1996). Tax knowledge and attitudes towards taxation: A report on a quasi-experiment. Journal of Economic Psychology, 17, 387-402.

[19] Internal Revenue Service Act 2000 (Act 592), (2000) Accra, Assembly Press. Internal

[20] Internal Revenue Service Act 2000 (Act 592), (2000) Accra, Assembly Press. Internal

[21] Revenue Act 2000 (Act 592), (2001) Accra, Assembly Press Internal Revenue Regulations, 2001 L.I.1675 (2001) Accra, Assembly Press

[22] James, S., and Alley, C. (2004). Tax Compliance, self-assessment and tax administration.

[23] James, S., and Nobes, C. (2000). The Economic of Taxation, 7th ed. London: Prentice Hall.

[24] John, A. (2013). The concept of taxes
[25] Kirchler, E. (2007). The Economic Psychology of Tax Behaviour. Cambridge: Cambridge University Press.

[26] Lewis, A. (1982). The Psychology of Taxation. Oxford: Martin Robertson.

[27] Lymer, A., and Oats, L. (2009). Taxation: Policy and Practice. 16th ed. Birmingham: Fiscal Publications.

[29] Lymer, A., and Hasseldine, J. (2002). Introduction to taxation in an international context Nasional, First Quarter, 16-23. Norgah J. H. (2006) Ghana Taxation; Accra, Linux LTD.

[30] Silvia, M. (2013). The Unconventional Guide to IAS 12 Tax Bases.

[31] www.pwc.com/gh

[32] Africapay.org/Ghana

[33] www.gra.gov.gh

[34] www.oxfordbusinessgroup.com 